Received 28.08.2015 Reviewed 23.09.2015 Accepted 14.10.2015

A - study design

B - data collection

C - statistical analysis

D - data interpretation

$\mathbf{E}$ - manuscript preparation

F - literature search

\title{
The stability of soil aggregates in tilled fallow areas in Hyderabad district, Pakistan
}

\author{
Ahmed TAGAR ${ }^{1) \text { ABCDEF }}$, Jan ADAMOWSKI ${ }^{2) \text { ABCDEF }}$
}

\begin{abstract}
1) Faculty of Agricultural Engineering, Sindh Agriculture University, Tandojam, Pakistan; ahmed_ali_tagar@hotmail.com
2) McGill University, Faculty of Agricultural and Environmental Sciences, Department of Bioresource Engineering, Quebec, Canada, H9X 3V9; e-mail: jan.adamowski@mcgill.ca
\end{abstract}

For citation: Tagar A., Adamowski J. 2015. The stability of soil aggregates in tilled fallow areas in Hyderabad district, Pakistan. Journal of Water and Land Development. No. 27 p. 51-60

\begin{abstract}
Arid areas are particularly susceptible to soil erosion due to long dry periods and sudden heavy downpours. This study investigates the aggregate size distribution and aggregate stability of twelve tilled fallow areas of Hyderabad district, Sindh, Pakistan. This study determined aggregate size distribution by dry sieving to evaluate the seedbed condition and aggregate stability using wet sieving to assess the susceptibility of tilled fallow areas to soil erosion. The aggregate size distribution of the soils of the selected areas was highly variable. Gulistan-e-Sarmast had the largest number of clods (51.0\%) followed by Kohsar (49.0\%), Latifabad \# 10 (41.10\%) and Daman-e-Kohsar (39.0\%). Fazal Sun City, the left side of the Indus River, the Village Nooral Detha and the left side of the Abdullah Sports city had a greater number of large $(>8.0 \mathrm{~mm})$ and small aggregates $(<0.5 \mathrm{~mm})$. The optimum aggregate size distribution was found in the left side of the channel, which had the largest number of aggregates $(50.50 \%)$ in the $0.5-8.0 \mathrm{~mm}$ sieve size range. Maximum aggregate stability (AS) was found in Gulistan-e-Sarmast (46\%), Kohsar (42\%) and Latifabad \# 10 (34\%), while all other soils had minimum aggregate stability $(<14 \%)$. The minimum aggregate stabilities demonstrate that the tilled fallow areas of Hyderabad district are highly susceptible to erosion. Therefore, the present study suggests investigating potential ways to enhance the aggregate stabilities of soils.
\end{abstract}

Key words: aggregate size distribution, aggregate stability, seedbed condition and soil erosion, tilled fallow areas

\section{INTRODUCTION}

Soil structure is a key indicator of soil quality, and the agricultural system more generally [TAGAR et al. 2014; 2015a, b]. It supports plants with sufficient water supply, aeration and the release of available nutrients [ALVAREZ et al. 2012]. Additionally, it protects organic matter [LÜTZOW et al. 2006] and reduces soil erosion [OADES 1984]. However, prolonged exposure of soils associated with insufficient residue inputs may cause declines in aggregation and soil organic matter, both of which make soil susceptible to erosion [PINHEIRO et al. 2004].
Soil erosion is defined as the detachment, transportation and deposition of soil particles and soil aggregates by wind and water [LAL 1994]. It is a serious environmental, economic, and social problem in semiarid and arid regions worldwide, which not only causes severe land degradation and loss of soil productivity, but also threatens the stability and health of society as well as the sustainable development of rural areas [ZHENG et al. 2004]. According to LAL [2001], the total land area subjected to soil degradation is estimated at about 2 billion hectares. Of this, about 1100 million hectares (mha) of land area is affected by water erosion and 550 mha of land area is affected by 
wind erosion. Given the anticipated changes in climate (e.g., ADAMOWSKI et al. [2009; 2010; 2012a, b], NALLEY et al. [2012; 2013], CAMPISI et al. [2012], HAIDARY et al. [2013], PINGAle et al. [2014], BELAYNEH et al. [2014], TIWARI and ADAMOWSKI [2014], RATHINASAMY et al. [2014], NOURANI et al. [2014]), this situation will likely worsen over the course of the next several decades. In Pakistan, the total land area affected is $79.61 \mathrm{mha}$, with $7.2 \mathrm{mha}$ land area beingaffected by water erosion and 10.7 mha land area affected by wind erosion.

The evaluation of soil erosion in the field is often expensive and time consuming. Soil aggregate stability is therefore an important property that may quantify and predict erosion [ZHANG, HORN 2001]. AN et al. [2009] concluded that the measurements of aggregate stability indicate that the soil water-stable aggregate contents reflect the ability of the soils to resist erosion. This is consistent with LE BISSONNAIS et al. [2007], who concluded that aggregate soil stability is closely correlated to the susceptibility of soil to erosion. Indeed, SHEIN et al. [2010] concluded that the differences in soil aggregate stability may largely influence soil's susceptibility to erosion.

Soil aggregate stability is the ability of the soil to retain its arrangement of solids and pore spaces after the application of mechanical stress or destructive forces [DIAZ-ZORITA et al. 2002]. Maintaining high soil aggregate stability is essential for preserving soil productivity and for minimizing soil erosion and environmental pollution that result from soil degradation. ARSHAD and COHEN [1992] proposed that aggregate stability is one physical soil properties that can serve as a soil quality indicator. HORTENSIUS and WELLING [1996] included aggregate stability in the international standardization of soil quality measurements.

A large number of soils in developing countries are tilled and are left fallow due to the scarcity of water or paucity of funds. However, sudden heavy downpours due to climatic changes erode the top fertile layers of these soils, making them unfertile or not suitable for cropping. This is consistent with LEGOUT et al. [2005], who concluded that heavy precipitation events, splash impact and slaking causes soil aggregates to break down into very fine particles and micro-aggregates, which may become highly erodible in water. According to HUSSAIN et al. [2010], Hyderabad, Pakistan received $105 \mathrm{~mm}$ of rain in 12 hours contributing towards a sudden flood event in February of 2003. 2006 and 2007 followed with close to this record rainfall with an estimated death toll ranging into the hundreds. On July 18, 2009, a total of 110 $\mathrm{mm}$ rain lashed the city, setting a new record. Accordingly, the present study was designed to investigate the stability of soil aggregates in tilled fallow areas of Hyderabad district in Pakistan in order to: (i) investigate the effect of tilled fallow areas on aggregate soil size distribution and the structural stability of soil.

\section{MATERIALS AND METHODS}

Soil samples were obtained from 12 tilled fallow soils of Hyderabad district of Sindh province, Pakistan. It is located at $68^{\circ} 17^{\prime} 30^{\prime \prime}-68^{\circ} 38^{\prime} 40^{\prime}$ 'E longitude $25^{\circ} 09^{\prime} 30^{\prime \prime}-25^{\circ} 33^{\prime} 12^{\prime \prime} \mathrm{N}$ latitude with an elevation of approximately $13 \mathrm{~m}$ above mean sea level (MSL). Figure 1 indicates the names and locations of selected sites of Hyderabad district. The climate of Hyderabad is hot and arid with an average annual rainfall of $136.1 \mathrm{~mm}$, average maximum temperature of $40^{\circ} \mathrm{C}$ and humidity of $55-60 \%$.

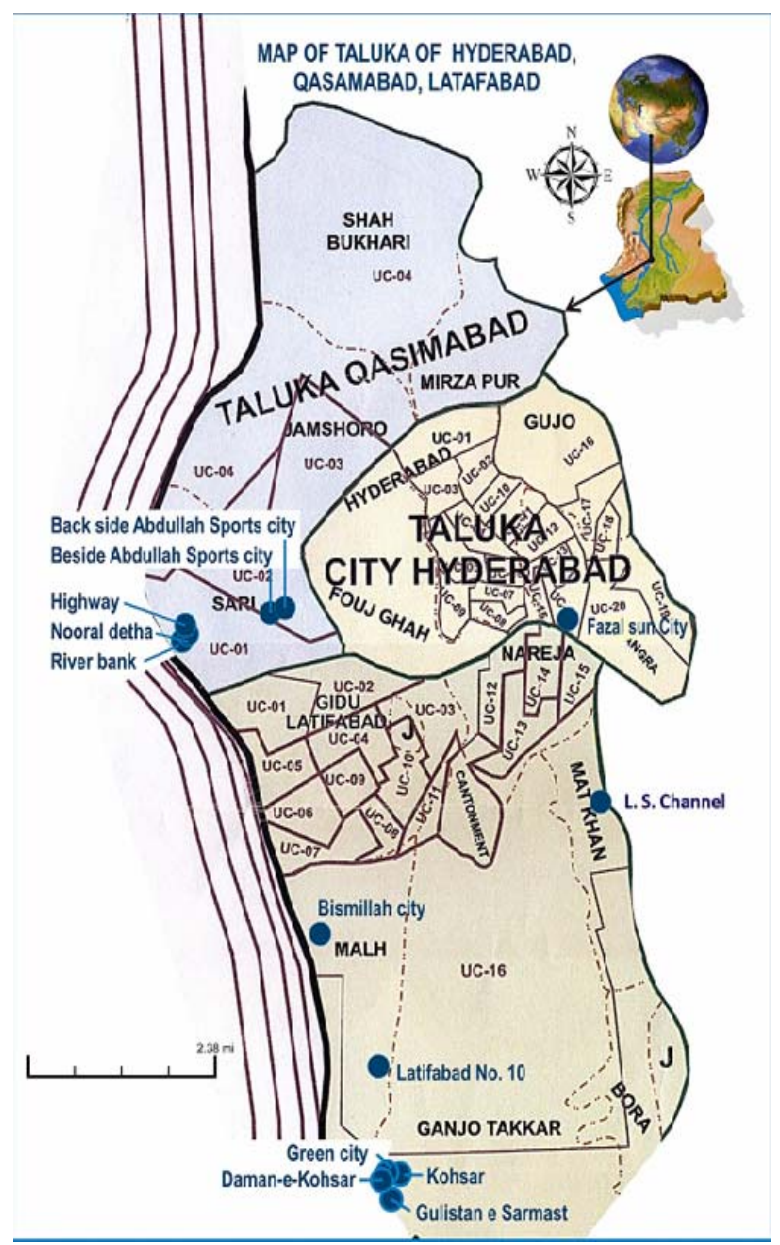

Fig. 1. Names and locations of selected sites of Hyderabad district, Sindh Province, Pakistan; source: own elaboration

\section{SOIL SAMPLING}

Three soil samples (one from the center and two from each side) were collected from the top $0-10 \mathrm{~cm}$ layer of each site. Litter, rock fragments and surface crusts, were removed prior to sampling. The samples were stored in aluminium containers, labeled and brought to the laboratory and then left for air drying at room temperature for 15 days. Similar soil samples were taken for the determination of soil texture and organic matter. 
Soil textural class was determined by the hydrometer method [BouYOUCOS 1927], in which $50 \mathrm{~g}$ of oven dry soil was sieved through a $2 \mathrm{~mm}$ sieve and added to a dispersing cup, with $400 \mathrm{~mL}$ of distilled water. $100 \mathrm{~mL}$ of sodium hectametaphosphate was then added to the cylinder, which was filled to the one liter mark with distilled water. The first reading of the hydrometer was taken after 40 seconds, and a second reading taken after 2 hours to determine the percentages of sand, silt and clay. To measure the dry bulk density of tilled soils, aggregates were placed in an empty container $(100 \mathrm{~mL})$, slightly compacted to remove empty spaces, and weighed with a digital balance to the nearest $0.0001 \mathrm{~g}$. The soil weight was then divided by the total volume of the container to obtain the dry bulk density, following the method adopted by ZHANG et al. [2012].

Organic matter content was determined using the WALKLEY and BLACK [1934] method. $1 \mathrm{~g}$ of soil was passed through a $2 \mathrm{~mm}$ sieve and weighed into a 500 mL conical flask. $10 \mathrm{~mL}$ of $1 \mathrm{~N} \mathrm{~K}_{2} \mathrm{Cr}_{2} \mathrm{O}_{7}$ was added; the flask was swirled, and concentrated $\mathrm{H}_{2} \mathrm{SO}_{4}(20$ $\mathrm{mL}$ ) was rapidly added and the flask again swirled for one minute. The flask was allowed to stand on an in- sulating (asbestos) sheet for 30 minutes, after which deionized water $(200 \mathrm{~mL})$ was added to the flask followed by three to four drops of o-phenanthroline indicator solution. Titration was conducted with Fe $\left(\mathrm{NH}_{4}\right) 2\left(\mathrm{SO}_{4}\right) 2(0.5 \mathrm{M})$ solution. A blank was also run in the same manner without soil to standardize $\mathrm{K}_{2} \mathrm{Cr}_{2} \mathrm{O}_{7}$. The organic carbon content in the soil was then calculated using the following equation:

$$
O . C(\%)=\frac{(B-S) \cdot N \cdot 0.003 \cdot 100}{W t \text { of soil }}
$$

where:

$$
\begin{aligned}
B= & \text { the volume of standard } 0.5 \mathrm{~N} \text { ferrous ammo- } \\
& \text { nium sulphate required to titrate the blank; } \\
S= & \text { is the volume of standard } 0.5 \mathrm{~N} \text { ferrous am- } \\
& \text { monium sulphate required to titrate the soil } \\
& \text { sample; }
\end{aligned}
$$

\begin{tabular}{|c|c|c|c|c|c|c|}
\hline \multirow[b]{2}{*}{ Name of sites } & \multicolumn{3}{|c|}{ Particle size distribution (\%) } & \multirow[b]{2}{*}{ Textural class } & \multirow{2}{*}{$\begin{array}{c}\text { Dry bulk } \\
\text { density } \\
\mathrm{g} \cdot \mathrm{cm}^{-3}\end{array}$} & \multirow{2}{*}{$\begin{array}{c}\text { Soil organic } \\
\text { matter } \\
\%\end{array}$} \\
\hline & $\begin{array}{c}\text { sand } \\
(0.05-0.2 \mathrm{~mm})\end{array}$ & $\begin{array}{c}\text { silt } \\
(0.002-0.05 \mathrm{~mm})\end{array}$ & $\begin{array}{c}\text { clay } \\
<0.002 \mathrm{~mm} \\
\end{array}$ & & & \\
\hline Kohsar & 35.4 & 22.3 & 42.3 & clay & 1.23 & 1.61 \\
\hline Near Fateh Farm & 40.4 & 35.7 & 23.9 & loam & 1.21 & 0.69 \\
\hline Daman-e-Kohsar & 51.3 & 22.3 & 26.4 & sandy clay loam & 1.25 & 0.53 \\
\hline Latifabad \# 10 & 47.0 & 29.1 & 23.9 & loam & 1.20 & 1.49 \\
\hline Back side of the Abdullah sports city & 45.4 & 30.7 & 23.9 & loam & 1.24 & 0.52 \\
\hline Fazal Sun City & 54.5 & 10.7 & 34.8 & sandy clay loam & 1.26 & 0.56 \\
\hline Left side of the Abdullah sports city & 57.9 & 13.2 & 28.9 & sandy clay loam & 1.25 & 0.59 \\
\hline Left side of the channel & 42.0 & 10.7 & 47.3 & clay & 1.22 & 0.65 \\
\hline Gulistan-e-Sarmast & 39.5 & 20.7 & 39.8 & clay loam & 1.23 & 2.19 \\
\hline Green city & 37.0 & 33.2 & 29.8 & clay loam & 1.27 & 0.51 \\
\hline Left side of the Indus River & 40.4 & 30.7 & 28.9 & clay loam & 1.21 & 0.54 \\
\hline Village Nooral Detha & 37.9 & 33.2 & 28.9 & clay loam & 1.22 & 0.51 \\
\hline
\end{tabular}

Table 1 indicates soil organic matter, dry bulk density and textural class of selected sites.

Table 1. Soil organic matter, dry bulk density and textural class of selected sites

Source: own elaboration.

\section{AGGREGATE SIZE DISTRIBUTION}

Mean weight diameter $(M W D)$ was used to determine the aggregate soil size distribution. Through this method, soil samples were passed through a nest of nine (9) sieve size classes: $32-25,25-12,12-8$, $8-4,4-2,2-1,1-0.5,0.5-0.25$ and $<0.25 \mathrm{~mm}$, respectively. The proportion of soil aggregates retained on each size class was collected and weighed. Mean weight diameter $(M W D)$ was calculated using following formula [VAN BAVEL 1949]:

$$
M W D=\sum x_{i} w_{i}
$$

where:

$$
\begin{aligned}
M W D= & \text { the mean weight diameter; } \\
x_{i}= & \text { the mean diameter of the } i \text { th sieve size; } \\
w_{i}= & \text { the proportion of the total aggregates in } \\
& \text { the } i \text { th fraction. }
\end{aligned}
$$

\section{AGGREGATE STABILITY $(A S)$}

Aggregate stability of the soil was determined using the wet sieving method of KEMPER and ROSENAU [1986]. In this method $50 \mathrm{~g}$ of air dried soil passed through an $8 \mathrm{~mm}$ sieve was pre-soaked for 30 minutes with distilled water and then transferred to the top most of the nest of sieves of 2.00, 1.00, 0.50, and 0.25 $\mathrm{mm}$ mesh sizes respectively. Subsequently soil in the nest of sieves was oscillated in distilled water at 30 oscillations per minute for a period of ten minutes. The aggregate stability was evaluated using the following formula [PICCOLO, MBAGWU 1999]:

$$
\begin{array}{ll}
\qquad A S=\frac{W S A>0.25 \mathrm{~mm}-W t \text { of sand }}{W t \text { of soil }-W t \text { of sand }} \cdot 100 \\
\text { where: } \\
\begin{array}{cl}
A S & =\text { aggregate stability, } \% ; \\
W S A & =\text { water stable aggregates; }
\end{array}
\end{array}
$$


$W t$ of sand = oven-dry weight of sand, g;

$W t$ of soil = as in eq. (1).

\section{STATISTICAL ANALYSIS}

Statistical analysis was performed using statistical software package SPSS-16.0 [SPSS 2007]. One way analysis of variance (ANOVA) was used to determine the effect of tilled fallow areas on mean weight diameter, aggregate stability, water stable aggregates and aggregate size distribution. The means were compared by the least significant difference method (LSD) at $P=0.05$.

\section{RESULTS AND DISCUSSION}

Statistical analysis of the results revealed that the tilled fallow areas had significant $(P<0.05)$ effects on mean weight diameter, aggregate stability, water stable aggregates and aggregate size distribution. Tables 2-5 show the descriptive statistics in the form of mean, standard deviation, range, $F$-values and $P$-values of mean weight diameter, aggregate stability, water stable aggregates and aggregate size distribution for selected sites of Hyderabad district. Previous studies have reported that a healthy seedbed should have more than $50 \%$ of soil aggregates by weight in the range of 0.5-8.0 mm [BRAUNACK, DEXTER 1989]. This is consistent with MUNKHOLM [2002], who concluded that a very large fraction of small aggregates (i.e. $<0.5-1.0 \mathrm{~mm}$ ) is not desirable, because of increased risk of wind and water erosion, while a very large fraction of aggregates larger than $8 \mathrm{~mm}$ is not desirable due to a reduction in the soil/root contact area and a higher impedance to root penetration. Indeed ADAM and ERBACH [1992] concluded that large proportions of very fine soil aggregates and clods in the seedbed can cause poor seed germination and delayed seedling emergence. Therefore in this study, the optimum seedbed was assumed to produce greater than $50 \%$ of aggregates by weight in the range of 0.5 to $8.0 \mathrm{~mm}$. Figure 2 illustrates the mass fraction $(\%)$ of soils of selected sites from different sieve sizes $(\mathrm{mm})$ obtained by dry-sieving. Gulistan-e-Sarmast had largest number of clods $(51.0 \%)$ followed by Kohsar (49.0\%), Latifabad \# 10 (41.10\%) and Daman-e-Kohsar (39.0\%). Fazal Sun City, the left side of the Indus River, Village Nooral Detha and the left side of the Abdullah Sports city had a greater number of large $(>8.0 \mathrm{~mm})$ and small aggregates $(<0.5 \mathrm{~mm})$. The optimum aggregate size distribution was found in left side of channel, which had the largest number of aggregates $(50.50 \%)$ in the $0.5-8.0 \mathrm{~mm}$ sieve size range. These differences may be the result of different land use and tillage practices. This is consistent with HEVIA et al. [2007], who found differences in aggregate soil size distribution in different soils associated with different tillage practices. GAJIĆ et al. [2013] reported more than 33\% of the dry aggregates in grassland habitats and only $20 \%$ of those in the arable soil to fall within the $1-5 \mathrm{~mm}$ sieve size range. Further, our results are comparable to $\mathrm{COTCH}-$ ING et al. [2002], who concluded that a significantly higher content of dry soil aggregates at a depth of 75 $\mathrm{mm}$ of cultivated soils as compared to a similar depth zone for long-term pasture soils. Indeed BROERSMA et al. [1997] concluded that the Gray Luvisolic soil in Canada had fewer large aggregates and more small aggregates than other cropping systems.

Table 2. Mean, standard deviation, range, $F$-values and $P$-values of mean weight diameter for selected sites of Hyderabad district

\begin{tabular}{|c|c|c|c|c|c|}
\hline \multirow[b]{2}{*}{ Name of sites } & \multicolumn{5}{|c|}{ Mean weight diameter } \\
\hline & mean & $\begin{array}{l}\text { standard } \\
\text { deviation }\end{array}$ & range & $F$-value & $P$-value \\
\hline Kohsar & 8.7033 & 0.04726 & 0.09 & \multirow{12}{*}{ 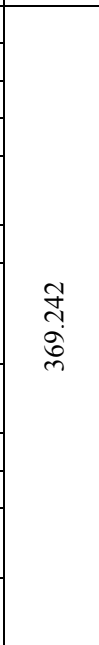 } & \multirow{12}{*}{$\stackrel{8}{\circ}$} \\
\hline Near Fateh Farm & 7.4767 & 0.03055 & 0.06 & & \\
\hline Daman-e-Kohsar & 7.3333 & 0.04726 & 0.09 & & \\
\hline Latifabad \# 10 & 8.3000 & 0.20000 & 0.40 & & \\
\hline $\begin{array}{l}\text { Back side Abdul- } \\
\text { lah sports city }\end{array}$ & 7.1533 & 0.03215 & 0.06 & & \\
\hline Fazal Sun city & 5.9500 & \begin{tabular}{|l|}
0.03000 \\
\end{tabular} & 0.06 & & \\
\hline $\begin{array}{l}\text { Left site of the } \\
\text { Abdullah sports } \\
\text { city }\end{array}$ & 7.4467 & 0.01528 & 0.03 & & \\
\hline $\begin{array}{l}\text { Left site of the } \\
\text { channel }\end{array}$ & 6.4700 & 0.03606 & 0.07 & & \\
\hline Gulistan-e-Sarmast & 9.0467 & 0.03786 & 0.07 & & \\
\hline Green city & 7.4767 & 0.03055 & 0.06 & & \\
\hline $\begin{array}{l}\text { Left site of the } \\
\text { Indus River }\end{array}$ & 5.0000 & 0.26458 & 0.50 & & \\
\hline $\begin{array}{l}\text { Village Nooral } \\
\text { Detha }\end{array}$ & 7.3533 & 0.04726 & 0.09 & & \\
\hline
\end{tabular}

Source: own study.

Table 3. Mean, standard deviation, range, $F$-values and $P$-values of aggregate stability for selected sites of Hyderabad district

\begin{tabular}{|c|c|c|c|c|c|}
\hline \multirow[b]{2}{*}{ Name of sites } & \multicolumn{5}{|c|}{ Aggregate stability } \\
\hline & mean & $\begin{array}{l}\text { standard } \\
\text { deviation }\end{array}$ & range & $F$-value & $P$-value \\
\hline Kohsar & 41.9667 & 2.13620 & 4.00 & \multirow{12}{*}{ 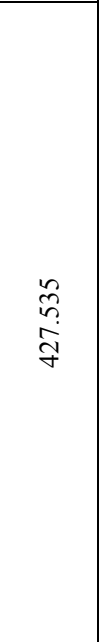 } & \multirow{12}{*}{\begin{tabular}{l}
$\stackrel{8}{8}$ \\
\hdashline \\
$\circ$
\end{tabular}} \\
\hline Near Fateh Farm & 9.5167 & 0.03055 & 0.06 & & \\
\hline Daman-e-Kohsar & 12.0000 & 1.77325 & 3.38 & & \\
\hline Latifabad \# 10 & 34.0000 & 1.63377 & 3.16 & & \\
\hline $\begin{array}{l}\text { Back side Abdul- } \\
\text { lah sports city }\end{array}$ & 5.5967 & 0.01528 & 0.03 & & \\
\hline Fazal Sun city & 5.2367 & 0.05033 & 0.10 & & \\
\hline $\begin{array}{l}\text { Left site of the } \\
\text { Abdullah sports } \\
\text { city }\end{array}$ & 10.4033 & 0.02082 & 0.04 & & \\
\hline $\begin{array}{l}\text { Left site of the } \\
\text { channel }\end{array}$ & 13.3033 & 0.04041 & 0.08 & & \\
\hline Gulistan-e-Sarmast & 46.0000 & 2.64575 & 5.00 & & \\
\hline Green city & 12.2033 & 0.04041 & 0.08 & & \\
\hline $\begin{array}{l}\text { Left site of the } \\
\text { Indus River }\end{array}$ & 9.2033 & 0.02082 & 0.04 & & \\
\hline $\begin{array}{l}\text { Village Nooral } \\
\text { Detha }\end{array}$ & 11.4033 & 0.02517 & 0.05 & & \\
\hline
\end{tabular}

Source: own study. 
Table 4. Mean, standard deviation, range, $F$-values and $P$-values of water stable aggregates for selected sites of Hyderabad district

\begin{tabular}{|c|c|c|c|c|c|c|c|c|c|c|}
\hline \multirow{3}{*}{ Name of sites } & \multicolumn{10}{|c|}{ Water stable aggregates } \\
\hline & \multicolumn{2}{|c|}{ mean } & \multicolumn{2}{|c|}{ standard deviation } & \multicolumn{2}{|c|}{ range } & \multicolumn{2}{|c|}{$F$-value } & \multicolumn{2}{|c|}{$P$-value } \\
\hline & $\begin{array}{c}0.25-2.0 \\
\mathrm{~mm}\end{array}$ & $<0.25 \mathrm{~mm}$ & $\begin{array}{c}0.25-2.0 \\
\mathrm{~mm}\end{array}$ & $<0.25 \mathrm{~mm}$ & $\begin{array}{c}0.25-2.0 \\
\mathrm{~mm}\end{array}$ & $<0.25 \mathrm{~mm}$ & $\begin{array}{c}0.25-2.0 \\
\mathrm{~mm}\end{array}$ & $\begin{array}{c}<0.25 \\
\mathrm{~mm}\end{array}$ & $\begin{array}{c}0.25-2.0 \\
\mathrm{~mm}\end{array}$ & $\begin{array}{c}<0.25 \\
\mathrm{~mm}\end{array}$ \\
\hline Kohsar & 18.963 & 81.00 & 1.788 & 2.000 & 3.35 & 4.00 & \multirow{12}{*}{133.86} & \multirow{12}{*}{100.74} & \multirow{12}{*}{0.000} & \multirow{12}{*}{0.000} \\
\hline Near Fateh Farm & 4.757 & 95.24 & 0.030 & 0.030 & 0.06 & 0.06 & & & & \\
\hline Daman-e-Kohsar & 6.003 & 94.00 & 1.641 & 1.951 & 3.19 & 3.82 & & & & \\
\hline Latifabad \# 10 & 17.000 & 83.00 & 2.216 & 2.062 & 4.30 & 3.90 & & & & \\
\hline $\begin{array}{l}\text { Back side Abdullah sports } \\
\text { city }\end{array}$ & 2.797 & 97.20 & 0.038 & 0.021 & 0.07 & 0.04 & & & & \\
\hline Fazal Sun city & 2.623 & 97.38 & 0.021 & 0.026 & 0.04 & 0.05 & & & & \\
\hline $\begin{array}{l}\text { Left site of the Abdullah } \\
\text { sports city }\end{array}$ & 5.203 & 94.80 & 0.050 & 0.030 & 0.10 & 0.06 & & & & \\
\hline Left site of the channel & 6.640 & 93.36 & 0.036 & 0.040 & 0.07 & 0.08 & & & & \\
\hline Gulistan-e-Sarmast & 22.997 & 77.00 & 1.398 & 1.977 & 2.79 & 3.79 & & & & \\
\hline Green city & 6.103 & 93.90 & 0.021 & 1.008 & 0.04 & 1.98 & & & & \\
\hline Left site of the Indus River & 4.603 & 95.40 & 0.030 & 0.036 & 0.06 & 0.07 & & & & \\
\hline Village Nooral Detha & 5.703 & 94.30 & 0.021 & 0.056 & 0.04 & 0.11 & & & & \\
\hline
\end{tabular}

Source: own study.

Table 5. Mean, standard deviation, range, $F$-values and $P$-values of aggregate size distributions for selected sites of Hyderabad district

\begin{tabular}{|c|c|c|c|c|c|c|c|c|c|c|c|c|c|c|c|}
\hline \multirow{3}{*}{ Name of sites } & \multicolumn{15}{|c|}{ Aggregate size distributions } \\
\hline & \multicolumn{3}{|c|}{ mean } & \multicolumn{3}{|c|}{ standard deviation } & \multicolumn{3}{|c|}{ range } & \multicolumn{3}{|c|}{$F$-value } & \multicolumn{3}{|c|}{$P$-value } \\
\hline & $\begin{array}{l}>8.0 \\
\mathrm{~mm}\end{array}$ & \begin{tabular}{|c|}
$0.5-8.0$ \\
$\mathrm{~mm}$
\end{tabular} & $\begin{array}{l}<0.5 \\
\mathrm{~mm}\end{array}$ & $\begin{array}{c}>8.0 \\
\mathrm{~mm}\end{array}$ & $\begin{array}{c}0.5-8.0 \\
\mathrm{~mm}\end{array}$ & $\begin{array}{l}<0.5 \\
\mathrm{~mm}\end{array}$ & $\begin{array}{c}>8.0 \\
\mathrm{~mm}\end{array}$ & \begin{tabular}{|c|}
$0.5-8.0$ \\
$\mathrm{~mm}$
\end{tabular} & $\begin{array}{l}<0.5 \\
\mathrm{~mm}\end{array}$ & $\begin{array}{c}>8.0 \\
\mathrm{~mm}\end{array}$ & $\begin{array}{c}0.5-8.0 \\
\mathrm{~mm}\end{array}$ & \begin{tabular}{|c|}
$<0.5$ \\
$\mathrm{~mm}$ \\
\end{tabular} & $\begin{array}{c}>8.0 \\
\mathrm{~mm}\end{array}$ & \begin{tabular}{|c|}
$0.5-8.0$ \\
$\mathrm{~mm}$
\end{tabular} & $\begin{array}{l}<0.5 \\
\mathrm{~mm}\end{array}$ \\
\hline Kohsar & 49.0 & 41.4 & 9.6 & 0.9 & 1.7 & 0.05 & 1.9 & 3.4 & 0.10 & & & & & & \\
\hline \begin{tabular}{|l} 
Near Fateh \\
Farm \\
\end{tabular} & 38.9 & 45.4 & 15.7 & 1.2 & 0.9 & 0.05 & 2.3 & 1.8 & 0.10 & & & & & & \\
\hline \begin{tabular}{|l|} 
Daman-e- \\
Kohsar \\
\end{tabular} & 39.0 & 39.4 & 21.6 & 1.1 & 2.0 & 0.06 & 2.2 & 3.9 & 0.12 & & & & & & \\
\hline Latifabad \# 10 & 41.1 & 47.2 & 11.6 & 1.2 & 1.8 & 0.05 & 2.3 & 3.7 & 0.09 & & & & & & \\
\hline \begin{tabular}{|l|} 
Back side \\
Abdullah \\
sports city
\end{tabular} & 34.1 & 44.2 & 20.8 & 1.1 & 1.8 & 0.03 & 2.2 & 3.4 & 0.06 & & & & & & \\
\hline Fazal Sun city & 27.6 & 36.3 & 36.0 & 1.7 & 1.5 & 1.7 & 3.2 & 3.0 & 3.0 & & & & & & \\
\hline \begin{tabular}{|l|} 
Left site of the \\
Abdullah \\
sports city
\end{tabular} & 38.0 & 38.3 & 23.7 & 1.0 & 0.9 & 0.05 & 2.0 & 1.9 & 0.10 & 92.5 & 26.4 & 844.9 & 0.00 & 0.00 & 0.00 \\
\hline $\begin{array}{l}\begin{array}{l}\text { Left site of the } \\
\text { channel }\end{array} \\
\end{array}$ & 30.3 & 50.5 & 19.2 & 2.1 & 1.5 & 0.03 & 4.04 & 2.9 & 0.05 & & & & & & \\
\hline \begin{tabular}{|l|} 
Gulistan-e- \\
Sarmast
\end{tabular} & 51.0 & 36.7 & 12.3 & 1.7 & 1.5 & 0.05 & 3.5 & 2.9 & 0.10 & & & & & & \\
\hline \begin{tabular}{|l|} 
Green city \\
\end{tabular} & 38.9 & 37.8 & 23.3 & 1.1 & 1.6 & 0.04 & 3.9 & 3.1 & 0.07 & & & & & & \\
\hline $\begin{array}{l}\text { Left site of the } \\
\text { Indus River }\end{array}$ & 21.8 & 44.6 & 33.6 & 1.3 & 1.4 & 0.04 & 2.6 & 2.8 & 0.08 & & & & & & \\
\hline $\begin{array}{l}\text { Village Nooral } \\
\text { Detha }\end{array}$ & 36.1 & 37.8 & 25.1 & 1.8 & 1.6 & 0.03 & 3.35 & 3.3 & 0.06 & & & & & & \\
\hline
\end{tabular}

Source: own study.

Figure 3 shows the mean weight diameter of soils of selected sites. Gulistan-e-Sarmast $(9.05 \mathrm{~mm})$ had the highest mean weight diameter $(M W D)$ followed by Kohsar $(8.7 \mathrm{~mm})$, and Latifabad \# $10(8.30 \mathrm{~mm})$; while the Fateh Farm, Daman-e-Kohsar, backside of the Abdullah Sports city, left side of the Abdullah Sports city, Green city and the village Nooral Detha had mean weight diameters ranging from 7.0 to 7.5 $\mathrm{mm}$. Fazal Sun city had $5.95 \mathrm{~mm} M W D$ and the left side of Indus River had 5.0 mm MWD. Mean weight diameter $(M W D)$ of Gulistan-e-Sarmast, Kohsar and Latifabad \# 10 was greater than other soils as shown in Figure 3. This is attributable the soil organic matter content. ROBERSON et al. [1991] concluded that mean weight diameter increases with soil organic matter (SOM) accumulation. This finding is also consistent with CASTRO-FILHO et al. [2002], who reported that $50 \%$ or higher $M W D$ in topsoil was associated with increased soil organic matter. 


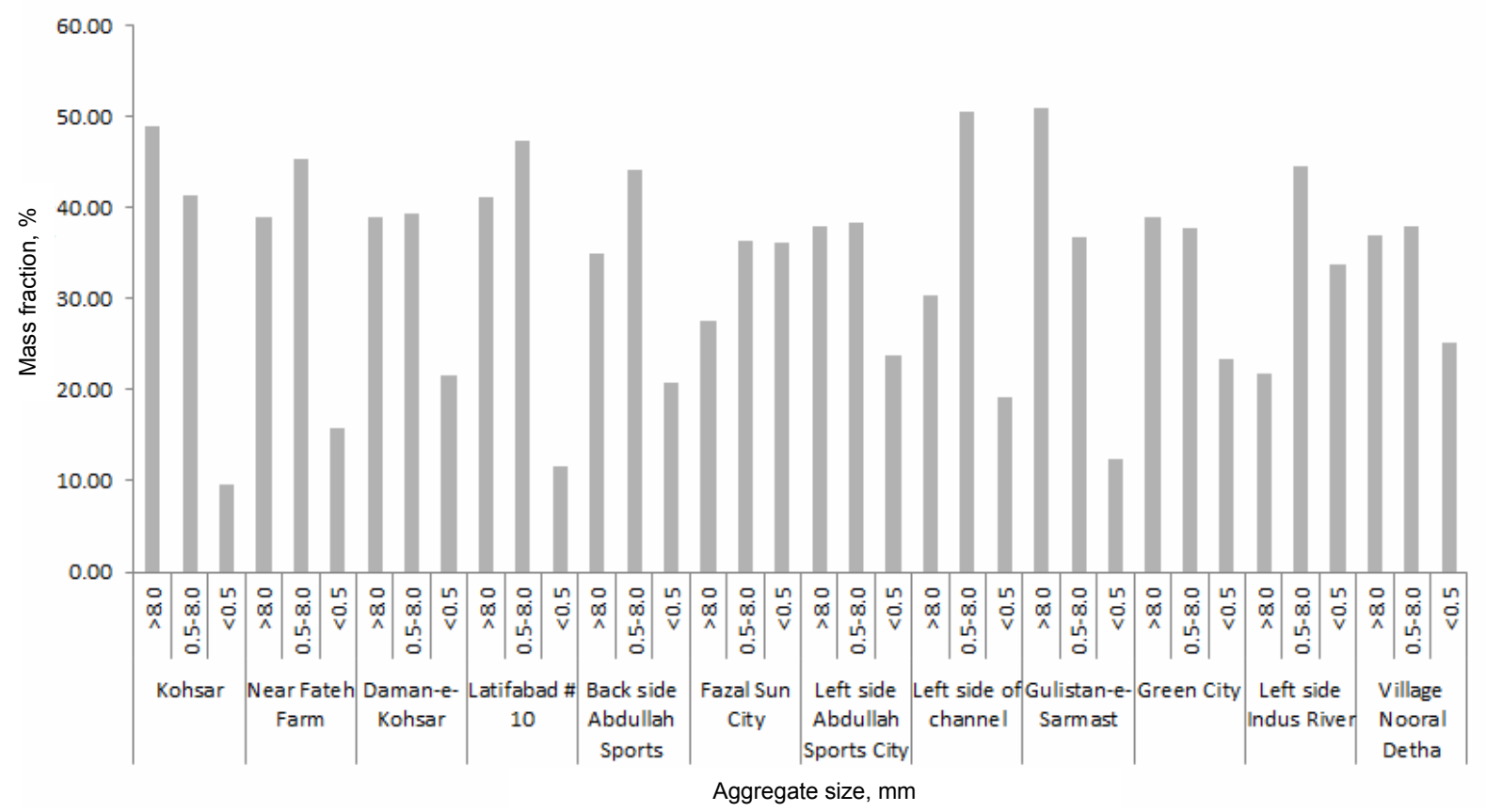

Fig. 2. Mass fraction (\%) of soils of selected sites in different sieve sizes (mm) obtained by dry sieving; source: own elaboration

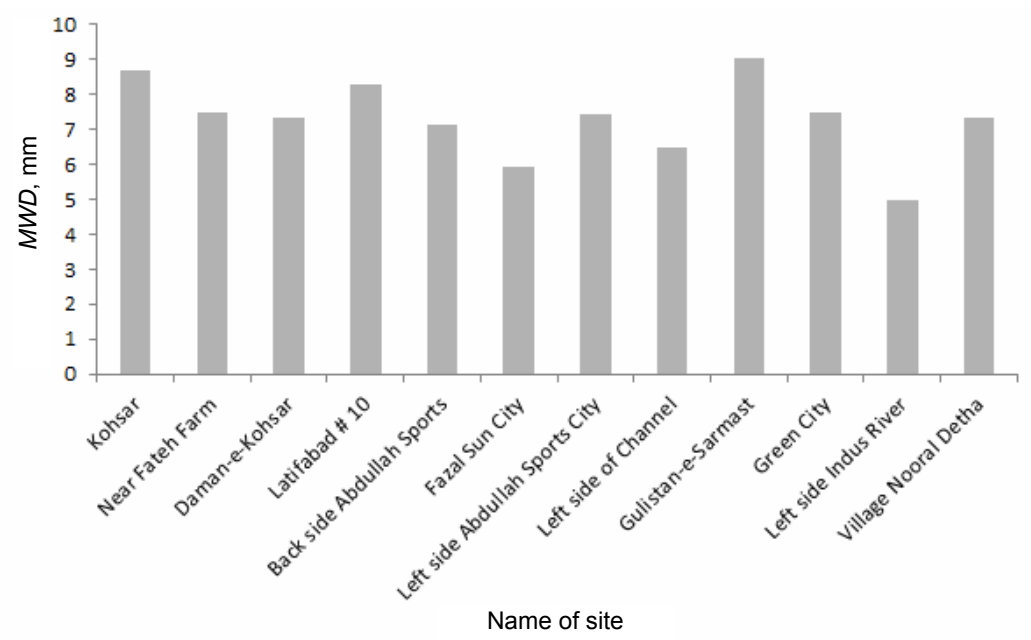

Fig. 3. Mean weight diameter $(M W D)$ of soils of selected sites; source: own study

Figure 4 shows the mass fraction (\%) of soils of selected sites in different sieve sizes $(\mathrm{mm})$ obtained by wet sieving. The largest number of water stable aggregates (WSA) was found in Gulistan-e-Sarmast (23.0\%) followed by Kohsar (19.0\%) and Latifabad \# $10(17.0 \%)$, while all other soils had smaller amounts of water stable aggregates (i.e. $<6.65 \%$ ). Figure 5 indicates aggregate stability (\%) of soils of selected sites. Maximum aggregate stability was found in Gulistan-e-Sarmast (46\%) followed by Kohsar (42\%), and Latifabad \# 10 (34\%), while all other soils had minimum aggregate stability (i.e. $<14 \%$ ). BROERSMA et al. [1997] found only $22-27 \%$ water stable aggregates $(>2.0 \mathrm{~mm})$ in the cultivated Gray Luvisolic soils. Similarly MARTENS et al. [2003] reported much lower aggregate stability of cultivated soils compared to forest and pasture soils. This is consistent with GAJIC and ZIVKOVIC [2006], who concluded that long term tilled soil had the lowest water stable aggregate $(>0.25 \mathrm{~mm})$ percentage. Indeed, EYNARD et al. [2004] concluded that the stability of soil aggregates usually decreased with cultivation. The higher aggregate stability in Gulistan-e-Sarmast, Kohsar and Latifabad \# 10 may be associated with the higher organic matter content. As was found by WOHLENBERG et al. [2004], this is attributable to higher water stable aggregates $(W S A)$ and soil aggregate stability $(A S)$ values in the surface layer $(0.00-0.50 \mathrm{~mm})$ associated with higher soil organic matter content. TISDALL and OADES [1982] reported that organic matter in the soil promotes aggregate stabilization through organic binding agents. 


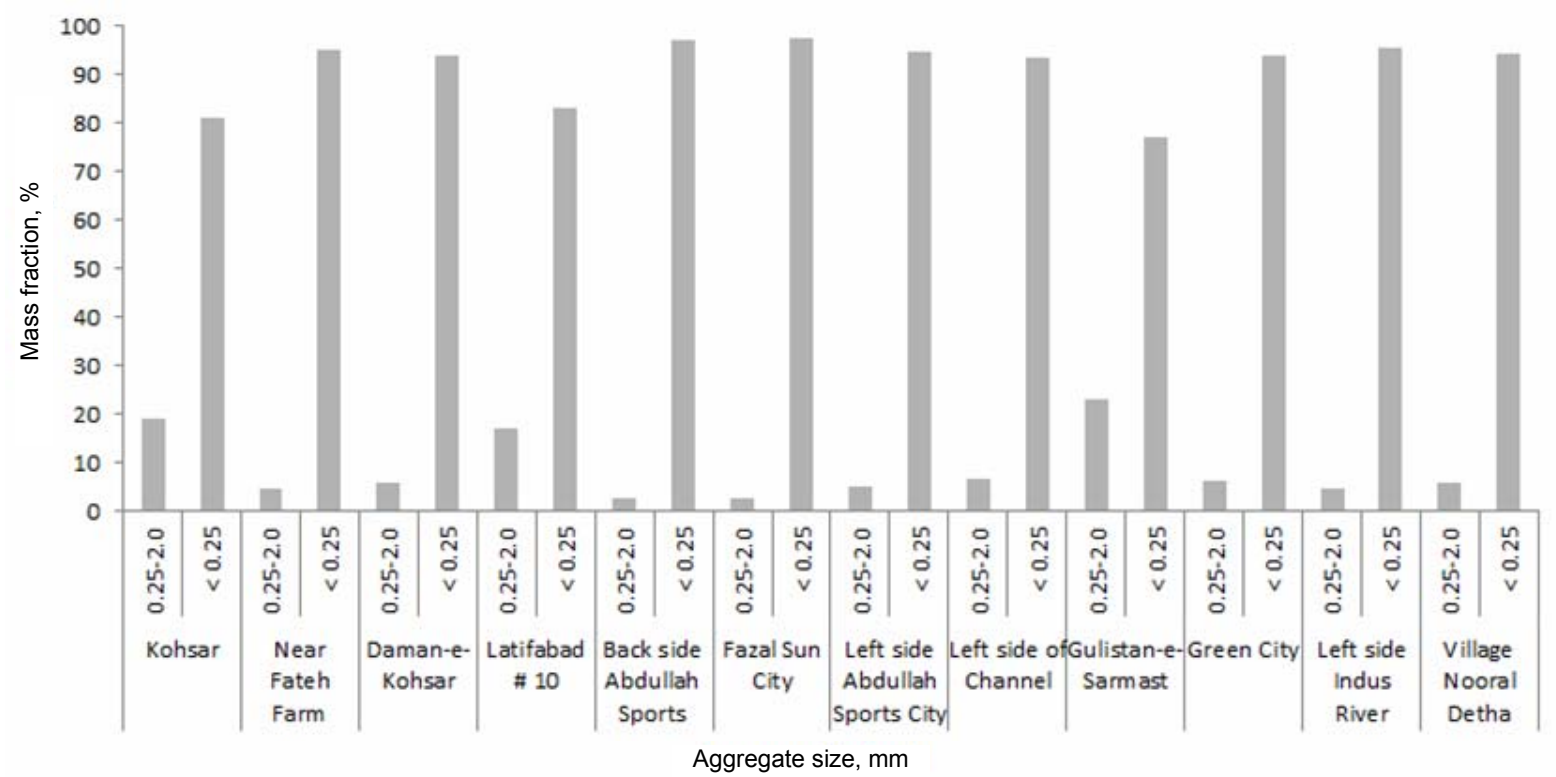

Fig. 4. Mass fraction (\%) of soils of selected sites in different sieve sizes (mm) obtained by wet sieving; source: own study

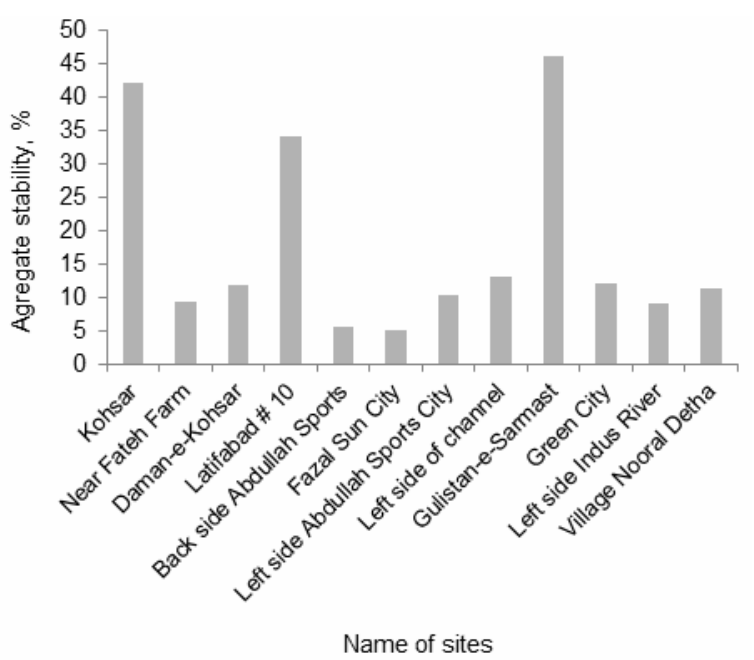

Fig. 5. Aggregate stability $(A S)$ of soils of selected sites; source: own study

\section{CONCLUSIONS}

The aggregate size distribution of soils of selected areas was highly variable. Gulistan-e-Sarmast had the largest number of clods followed by Kohsar, Latifabad \# 10 and Daman-e-Kohsar. Fazal Sun City, the left side Indus River, Village Nooral Detha and the left side Abdullah Sports city had a greater number of large (i.e. $>8.0 \mathrm{~mm}$ ) and small aggregates (i.e. $<0.5 \mathrm{~mm}$ ). The optimum aggregate size distribution was found in the left side of channel, which had largest number of aggregates $(50.50 \%)$ in the $0.5-8.0 \mathrm{~mm}$ sieve size range. The maximum aggregate soil stability (AS) was found in Gulistan-e-Sarmast, Kohsar and Latifabad \# 10, while all other soils had minimum aggregate stability. Lastly, Gulistan-e-Sarmast, Kohsar and Latifabad \# 10 had the greatest resistance to soil erosion, while all other soils were found highly susceptible to soil erosion. It is hoped that the infor- mation and results provided in this paper will help stakeholders transition to more sustainable natural resources management [HALBE et al. 2013; KOLINJIVADI et al. 2014a, b; SAADAT et al. 2011; STRAITH et al. 2011; INAM et al. 2015; BUTLER, ADAMOWSKI 2015].

\section{REFERENCES}

ADAM K.M., ERBACH D.C. 1992. Secondary tillage tool effect on soil aggregation. Transactions of the American Society of Agricultural Engineers. Vol. 35. Iss. 6 p.1771-1776.

ADAMOWSKi J., ADAMOWSKI K., Bougadis J. 2010. Influence of trend on short duration design storms. Water Resources Management. Vol. 24. Iss. 3. p. 401-413.

Adamowski J., Chan H., Prasher S., Sharda V.N. 2012a. Comparison of multivariate adaptive regression splines with coupled wavelet transform artificial neural networks for runoff forecasting in Himalayan microwatersheds with limited data. Journal of Hydroinformatics. Vol. 14. Iss. 3 p. 731-744.

AdAmowsKi J., Prokoph A., AdAmowski K. 2012b. Influence of the 11 year solar cycle on annual streamflow maxima in Southern Canada. Journal of Hydrology. Vol. 442 p. 55-62.

AdAmowski K., Prokoph A., AdAmowski J. 2009. Development of a new method of wavelet aided trend detection and estimation. Hydrological Processes. Vol. 23. Iss. 18 p. 2686-2696.

Alvarez M.F., Osterrieth M.L., Del Rio J.L. 2012. Changes on aggregates morphology and roughness induced by different uses of typical Argiudolls, Buenos Aires province, Argentina. Soil and Tillage Research. Vol. 119 p. 38-49.

AMÉZKETA E. 1999. Soil aggregate stability: A review. Journal of Sustainable Agriculture. Vol. 14. Iss. 2-3 p. 83-151.

AN S.S., HUANG Y.M., ZHENG F.L. 2009. Evaluation of soil microbial indices along a revegetation chronosequence 
in grassland soils on the Loess Plateau, Northwest China. Applied Soil Ecology. Vol. 41. Iss. 3 p. 286-292.

ArshaD M.A., COHEN G.M. 1992. Characterization of soil quality: physical and chemical criteria. American Journal of Alternative Agriculture. Vol. 7. Iss. 1-2 p. 25-32.

Belayneh A., ADAmowsKi J., Khalil B., OZga-Zielinski B. 2014. Long-term SPI drought forecasting in the Awash River Basin in Ethiopia using wavelet-support vector regression models. Journal of Hydrology. Vol. 508 p. $418-429$.

Bouyoucos G.J., 1927. The hydrometer as a new method for the mechanical analysis of soils. Soil Science. Vol. 23. Iss. 5 p. 343-353.

Braunack M.V., DeXTER A.R. 1989. Soil aggregation in the seedbed: A review. II. Effect of aggregate sizes on plant growth. Soil and Tillage Research. Vol. 14 p. 281298.

Broersma K., Robertson J.A., ChanAsyk D.S. 1997. The effects of diverse cropping systems on aggregation of a Luvisolic soil in the Peace River region. Canadian Journal of Soil Science. Vol. 77 p. 323-329.

ButLER C., ADAMOWSKI J. 2015. Empowering marginalized communities in water resources management: Addressing inequitable practices in Participatory Model Building. Journal of Environmental Management. Vol. 153 p. $153-162$.

CAMPISI S., ADAMOWSKI J., ORON G. 2012. Forecasting urban water demand via wavelet-denoising and neural network models. Case study: city of Syracuse, Italy. Water Resources Management. Vol. 26. Iss. 12 p. 35393558.

Castro-Filho C., Lourenço A., Guimaraes M.F., FonseCA I.C.B. 2002. Aggregate stability under different soil management systems in a red latosol in the state of $\mathrm{Pa}$ rana, Brazil. Soil and Tillage Research. Vol. 65 p. 4551.

Cotching W.E., Cooper J., Sparrow L.A., McCorkell B.E., Rowley W. 2002. Effects of agricultural management on Dermosols in northern Tasmania. Australian Journal of Soil Research. Vol. 40. Iss. 1 p. 65-79.

Diaz-Zorita M., Perfect E., Grove J.H. 2002. Disruptive methods for assessing soil structure. Soil and Tillage Research. Vol. 64 p. 3-22.

Eynard A., SChUmacher T.E., LindSTROM M.J., Malo D.D., Kohl R.A. 2004. Wettability of soil aggregates from cultivated and uncultivated Ustolls and Usterts. Australian Journal of Soil Research. Vol. 42. Iss. 2 p. $163-170$.

Gajić B., Tapanarova A., Tomić Z., Kresović B., VuJOVIĆ D., PEJIĆ B. 2013. Land use effects on aggregation and erodibility of Luvisols on undulating slopes. Australian Journal of Crop Science. Vol. 7. Iss. 8 p. 1198 1204.

GAJIĆ B., ŽıvKović M. 2006. Aggregate composition and stability of structural aggregates of non-calcareous rendzinas in Eastern Serbia. Journal of Agricultural Sciences. Vol. 51. Iss. 2 p. 141-150.

Haidary A., Amiri B.J., ADAMOWSKi J., Fohrer N., NAKANE K. 2013. Assessing the impacts of four land use types on the water quality of wetlands in Japan. Water Resources Management. Vol. 27 p. 2217-2229.

Halbe J., Pahl-Wostl C., Sendzimir J., Adamowski J. 2013. Towards adaptive and integrated management paradigms to meet the challenges of water governance. Water Science and Technology: Water Supply. Vol. 67 p. 2651-2660.
Hevia G.G., MendÉz M.J., Buschiazzo D.E. 2007. Tillage affects soil aggregation parameters linked with wind erosion. Geoderma. Vol. 140 p. 90-96.

HoRTENSIUS D., WELling R. 1996. International standardization of soil quality measurements. Communications in Soil Science and Plant Analysis. Vol. 27 p. 387-402.

Hussain M.A., AbBas S., ANSARI M.R.K. 2010. Forecast models for urban extreme temperatures: Karachi region as a case study. The Nucleus. Vol. 47. Iss. 4 p. 301-311.

InAm A., AdAmOWSKi J., HAlBe J., PRASHER S. 2015. Using causal loop diagrams for the initialization of stakeholder engagement in soil salinity management in agricultural watersheds in developing countries: A case study in the Rechna Doab watershed, Pakistan. Journal of Environmental Management. Vol. 152 p. 251-267.

KeMPER D.W., ROSENAU R.C. 1986. Aggregate stability and size distribution. In: Methods of soil analysis. 1. Ed. A. Klute. Am. Soc. Agron. Madison. WI. 9 p. 425-442.

KolinJiVADI V, ADAMOWSKI J, KosOY N. 2014a. Juggling multiple dimensions in a complex socioecosystem: The issue of targeting in payments for ecosystem services. GeoForum. 58: 1-13.

KolinjiVAdi V., ADAmowsKi J., Kosoy N. 2014b. Recasting payments for ecosystem services (PES) in water resource management: A novel institutional approach. Ecosystem Services. Vol. 10 p. 144-154.

LAL R. 1994. Soil erosion research methods. Soil and Water Conservation Society (Ankeny). 3rd edn. Delray Beach. St. Lucie Press pp. 340.

LAL R. 2001. Soil degradation by erosion. Land Degradation and Development. Vol. 12. Iss. 6 p. 519-539.

Le Bissonnais Y., Blavet D., De Noni G., Laurent J.Y., Asseline J., Chenu C. 2007. Erodibility of Mediterranean vineyard soils: Relevant aggregate stability methods and significant soil variables. European Journal of Soil Science. Vol. 58 p. 188-195.

Legout C., Leguedois S., Le Bissonnais Y. 2005. Aggregate breakdown dynamics under rainfall compared with aggregate stability measurement. European Journal of Soil Science. Vol. 56 p. 225-237.

LÜTZOW M., KÖGEL-KNABNER I., EKSChMitT K., MATZNER E., Guggenberger G., Marschner B., Flessa H. 2006. Stabilization of organic matter in temperate soils: mechanisms and their relevance under different soil conditions. European Journal of Soil Science. Vol. 57 p. $426-445$.

Martens D.A., ReEdy T.E., LewIS D.T. 2003. Soil organic carbon content and composition of 130-year crop, pasture and forest land-use managements. Global Change Biology. Vol. 10 p. 65-78.

MunKhOLM L.J. 2002. Soil Fragmentation and Friability. Effects of Soil Water and Soil Management. Ph.D. Thesis. Danish Institute of Agricultural Sciences, Department of Crop Physiology and Soil Science.

NALley D., AdAmowski J., Khalil B. 2012. Using discrete wavelet transforms to analyze trends in streamflow and precipitation in Quebec and Ontario (1954-2008). Journal of Hydrology. Vol. 475 p. 204-228.

NAlley D., AdAmowski J., Khalil B., OzGa-Zielinski B. 2013. Trend detection in surface air temperature in Ontario and Quebec, Canada during 1967-2006 using the discrete wavelet transform. Journal of Atmospheric Research. Vol. 132/133 p. 375-398.

Nourani V., Baghanam A., Adamowski J., Kisi O. 2014. Applications of hybrid wavelet-artificial intelligence models in hydrology: A review. Journal of Hydrology. Vol. 514 p. 358-377. 
OADES J.M. 1984. Soil organic matter and structural stability: mechanism and implications for management. Plant Soil. Vol. 76 p. 319-337.

Piccolo A., Mbagwu J.S.C. 1999. Role of hydrophobic components of soil organic matter in soil aggregate stability. Soil Science Society of America Journal. Vol. 63 p. 1801-1810.

Pingale S., Khare D., Jat M., AdAmowski J. 2014. Spatial and temporal trends of mean and extreme rainfall and temperature for the 33 urban centres of the arid and semi-arid state of Rajasthan, India. Journal of Atmospheric Research. Vol. 138 p. 73-90.

Pinheiro E.F.M., Pereira M.G., AnJos L.H.C. 2004. Aggregate distribution and soil organic matter under different tillage systems for vegetable crops in a Red Latosol from Brazil. Soil and Tillage Research. Vol. 77 p. 79-84.

Rathinasamy M., ADAmowski J., Khosa R. 2014. Multiscale streamflow forecasting using a new Bayesian model average based ensemble multi-wavelet Volterra nonlinear method. Journal of Hydrology. Vol. 507 p. 186-200.

Roberson E.B., SARIG S., Firestone M.K. 1991. Cover crop management of polysacchar-ides-mediated aggregation in an orchard soil. Soil Science Society of America Journal. Vol. 55 p. 734-739.

SAADAT H., ADAmOWski J., BonNell R., Sharifi F., NAMDAR M., Ale-Ebrahim S. 2011. Land use and land cover classification over a large area in Iran based on single date analysis of satellite imagery. Journal of Photogrammetry and Remote Sensing. Vol. 66 p. 608-619.

Shein E.V., Umarova A.B., Milanovskiy E.Y., SoKolova I.V. 2010. Preferential water flow, local soil biota and structure degradation in chernozem 20 years after landreclamation. International Agrophysics. Vol. 24 p. $75-$ 80.

SPSS Inc. 2007. SYSTAT version 16.0: Statistics. Chicago. Illinois.

StRAith D., AdAMOWSKi J., ReILly K. 2014. Exploring the attributes, strategies and contextual knowledge of champions of change in the Canadian water sector. Canadian Water Resources Journal. Vol. 39. Iss. 3 p. 255 269.

Tagar A., Changying J., Ding Q., Adamowski J. 2014. Soil failure patterns and draft as influenced by consis- tency limits: An evaluation of the remolded soil cutting test. Journal of Soil and Tillage Research. Vol. 137 p. $58-66$.

Tagar A., Changying J., Adamowski J. 2015a. Finite element simulation of soil failure patterns under soil bin and field testing conditions. Journal of Soil Tillage Research. Vol. 145 p. 157-170.

Tagar A., Changying J., Qishuo D., Adamowski J., CHANDIO F., MARI I. 2015b. Quantification of soil structures created after different failure patterns as influenced by soil consistency limits. Geoderma. Vol. 261 p. 124-132.

TISDALL J.M., OADES J.M. 1982. Organic matter and water stable aggregates in soils. Journal of Soil Science. Vol. 33 p. 141-163.

TIWARI M., ADAMOWSKI J. 2014. Urban water demand forecasting and uncertainty assessment using ensemble wavelet-bootstrap-neural network models. Water Resources Research. Vol. 49. Iss. 10 p. 6486-6507.

VAN BAVEL C.H.M. 1949. Mean weight diameter of soil aggregates as a statistical index of aggregation. Soil Science Society of America Journal. Vol. 14 p. 20-23.

WALKLEY A., BLACK I.A. 1934. An examination of the Degtjareff method for determining organic carbon in soils: Effect of variations in digestion conditions and of inorganic soil constituents. Soil Science. Vol. 63 p. 251-263.

Wohlenberg E.V., Reichert J.M., Reinert D.J., Blume E. 2004. Dinâmica da agregação de um solo francoarenosoemcincosistemas de culturasemrotação e emsucessão. Revista Brasileira de Ciência do Solo. Vol. 28 p. 891900.

Zhang Y., Ghaly A.E., BingXi L. 2012. Physical properties of wheat straw varieties cultivated under different climatic and soil conditions in three continents. American Journal of Engineering and Applied Sciences. Vol. 5. Iss. 2 p. $98-106$.

Zhang B., Horn R. 2001. Mechanisms of aggregate stabilization in Ultisols from subtropical China. Geoderma. Vol. 99 p. 123-145.

ZHENG F.L., YANG Q.K., WANG Z.L. 2004. Water erosion prediction model. Research of Soil and Water Conservation. Vol. 11. Iss. 4 p. 13-24.

\section{Ahmed TAGAR, Jan ADAMOWSKI}

\section{Trwałość agregatów glebowych na terenach użytkowanych rolniczo w dystrykcie Hyderabad, Pakistan}

\section{STRESZCZENIE}

Słowa kluczowe: grunty uprawne, rozkład wielkości agregatów glebowych, trwałość agregatów, warunki wysiewu i erozja gleby

Obszary o klimacie zwrotnikowym suchym są szczególnie podatne na erozję gleby z powodu długich okresów suszy i nagłych ulewnych opadów deszczu. W pracy przedstawiono wyniki badań rozkładu wielkości agregatów glebowych i ich trwałości w dwunastu uprawianych gruntach dystryktu Hyderabad w Sindh w Pakistanie. Rozkład wielkości agregatów oznaczano poprzez przesiewanie suchej gleby, a trwałość agregatów określano metodą przesiewania na mokro. Wielkości te charakteryzują podatność gleb uprawnych na erozję. Rozkład granulometryczny gleb na badanym obszarze był silnie zróżnicowany. Największą liczbę agregatów $(51,0 \%)$ zawierała gleba w Gulistan-e-Sarmast, mniejszą - gleba w Kohsar (49,0\%), Latifabad (41,1\%) i Daman-e-Kohsar 
$(39,0 \%)$. Gleby na terenie miasta Fazal Sun na lewym brzegu Indusu, gleby we wsi Nooral Detha i mieście Abdullah Sports charakteryzowały się znaczną liczbą dużych $(>8 \mathrm{~mm})$ i małych $(<0,5 \mathrm{~mm})$ agregatów. Optymalny rozkład wielkości agregatów glebowych stwierdzono na lewym brzegu kanału, gdzie gleba zawierała najwięcej (50,5\%) agregatów w przedziale wielkości 0,5-8,0 mm. Maksymalną trwałość agregatów wykazywały gleby w Gulistan-e-Sarmast (46\%), Kohsar (42\%) i Latifabad (34\%), trwałość agregatów pozostałych gleb była minimalna $(<14 \%)$. Stwierdzona minimalna trwałość agregatów świadczy, że gleby użytkowane rolniczo w dystrykcie Hyderabad są silnie podatne na erozję. Wyniki przedstawionych badań sugerują potrzebę poszukiwania sposobów na zwiększenie trwałości agregatów glebowych. 
